\title{
TRANSFORMATION OF THE CONCEPT "NATIONAL INTERESTS" IN THE CONTEXT OF GLOBALIZATION
}

\author{
(c) Radima H. Denilkhanova, Ramzan H. Daudov \\ Chechen State University, Grozny, Russian Federation \\ radima1@yandex.ru, sapsan189@mail.ru
}

The article is a study of the national interests of the state through the prism of impact factors on their definition and priorities for the country's development at the present stage; a broader understanding of national state interests that are of great importance in the life of society and affect the economic development of the country is given; it is emphasized that the doctrine of national interest still relies on the value-normative positions and ideologies of states even during intensively developing globalization processes, the nation is both the starting point of the formation of the state, and the expression of a more complete, comprehensive life force, creative source, socially important for society and the individual aspects; it is pointed out that due to the contradictions of the interests of different States there are big conflicts, but in international relations they are most commonly caused by inaccurate and/or incomplete certain and incorrectly perceived interests of the nation or taken measures of national security.

Key words: national interests, "designing" of national interests, nation-building, national identity, globalization, transformation, nation.

\section{[P.X. Денильханова, P.X. Даудов Трансформация понятия "национальные интересы" в условиях глобализации]}

Статья представляет собой исследование национальных интересов государства через призму факторов воздействия на их определение и приоритеты развития государства на современном этапе; дается расширенное понимание национально-государственных интересов, имеющих большое значение в жизни общества и влияющих на экономическое развитие страны; подчеркнуто, что доктрина национального интереса все так же опирается на ценностно-нормативные позиции и идеологии государств даже во время интенсивно развивающихся глобализационных процессов; нация является и исходной точкой образования государства, и выразителем более полной, всеобъемлющей жизненной силы, творческого истока, социально важных для социума и отдельной личности аспектов; указывается на то, что из-за противоречий интересов разных государств возникают большие конфликты, но они в междунациональных отношениях чаще всего обусловлены неточно и/или неполно определенными и неправильно воспринятыми интересами нации или предпринятыми мерами национальной безопасности.

Ключевые слова: национальные интересы, «конструирование» национальных интересов, нациестроительство, национальное самосознание, глобализация, трансформация, нация.

Radima H. Denilkhanova - Candidate of philosophical sciences, associate professor of Department of Philosophy, Chechen State University. Grozny, Russian Federation.

Денильханова Радима Хаважовна - кандидат фрилософрских наук, доцент кафредры философии Чеченского государственного университета. г. Грозный, Российская Федерация.

Ramzan H. Daudov - Senior lecturer of Department of Philosophy Chechen State University. Grozny, Russian Federation.

Даудов Рамзан Хожаевич - старший преподаватель кафедры фрилософрии Чеченского государственного университета. г. Грозный, Российская Федерация.

The controversy among Russian scientists around national interest that has continued for the past twenty years has reflected the same lack of unanimity in the awareness of this category [9, p. 977]. 
Like foreign political scientists, our theorists were divided in the dispute not so much into supporters or opponents of objectivism, but rather into adherents of realism or liberalism paired with idealism. Realists believe that the national interest maintains its dominant position for all countries on the planet. Therefore, to treat it with disdain would be not just a mistake, but even a danger [4, p. 80]. In other words, the national interest, in their opinion, is not limited to the spectrum of civil interests, because in addition to generalizing joint interests, it takes into account a large number of real socio-economic, geostrategic and other factors. The formation of national interests occurs under the influence of global processes in the economy, politics of other countries etc. [7, p.100].

Liberals believe that "there is an exaggeration of the role of interests of the nation (the concept is not deterministic, but it means, most likely, something that has a material basis, for example, oil products, finance, land, armed forces) and an underestimation of the value of more sensitive psychological aspects" [12, p.11]. Representatives of liberalism believe that the formation of a nation's interest in a democratic society takes place by generalizing individual interests, and a totalitarian society is based on a "sovereign" view, which means that the interests of the nation prevail over individual interests [13, p. 468]. The interests of the nation must be understood as the "interests of the people", which causes the realization that "what unbearable weight of the negative historical heritage is emanating from this concept, and what danger its unlimited use may pose" [5, p.108].

Foreign scientists tend to distinguish between national and public interests. They interpret national interests from the point of view of the general course of powers in international affairs, and the interests of society, in their understanding, are in the domestic political dimension and affect the sphere of politics, national economy, social life and other areas of the functioning of society within the country.

Based on the system of coordinates supported by western authors regarding international relations, interpretations similar to the "foreign policy aspect of national interests" contain a tautology and lead to concealment of the essence of the matter. So, putting an equal sign between these concepts, you can gradually either reduce the interest of the nation to public interest, as a result of reducing the foreign policy to domestic, or separate it from the interest of the state, allowing to consider the foreign policy objectives of power, the interests of people and ethnic groups as diametrically.

It seems that the interests of society and national interests are complementary gaps of each other, and not mutually exclusive concepts. There is no doubt about the subordination of the interests of society to some extent to the events taking place in the world. At the same time, national interests depend on the position of the economy within the state, the level of its stability in the social and political segment, and the moral and civic atmosphere in society. In addition, a significant role is played by the fact that countries with economies in transition are characterized not only by focusing on the mutual influence of national and social interests, but also by strengthening the positions of public interests and their priority position over national interests. That is exactly the present state of Russia. Therefore, the distinction between national interests on internal and external interests, proposed by the Concept of National Security of the Russian Federation, can be considered fully justified.

Одновременно с этим, конструкционно общенациональные интересы сейчас более сложны, что обусловлено неизбежностью появления новых вызовов (поступающих из-за рубежа и имеющихся внутри страны), на которые требуется дать ответ.

Based on the existing realities, the Russian domestic political national interests need an overarching focus on the main problem. This is the need to revive the country, its national economy and the well-being of people. The foreign policy course should reflect this task in a comprehensive form both at the ideological and conceptual, and at the operational level. In other words, in the mutual action of national and public interests against each other, the latter are of paramount importance. At the same time, structurally the national interests are now 
more complex, which is due to the inevitability of the emergence of new challenges (both: coming from abroad and existing within the country), which need to be answered.

The process of awareness of such a specific concept as a national interest is distinguished by abstractness and subjectivity. The identification of this category depends directly on the pattern of relations to the whole surrounding and the value system that dominates this moment in a particular society and country. J. Rosenau believed that "determination of the interest of a nation is always a system of conclusions based on the analytical and value foundation of politics" [14, p.1126]. Hence, it is possible to characterize the interest of a nation only in the course of its implementation. Accordingly, this implies the exploitation of effective and oriented measures, as well as means for accomplishing the tasks the state faces. This means that the political process is the main instrument for the realization of national interests.

Speaking about the state, as a national entity or nation-state, which takes an active part in relations between countries and is a leading element of these relations, it is quite reasonable to represent national interests and interests of the state as interrelated and complementary categories.

The regulation of the duality of state interest and the interests of civil society is realized in the spirit of understanding not only their semantic connection with the national interest, but also the fact that they establish to a large extent its meaningful architecture. In this context, the opinion of authors who prefer to use the term "national state interests" is significant. Moreover, it is important to remember that it is the state that is charged with the duty of representing the nation to the world community. And this means that in the framework of foreign policy, national interests mean the interests of the state, and the interests of the state, respectively, imply national interests.

In the general system of interests, national interests are articulated on the country's geopolitical data and resource capabilities, taking into account a large number of intertwined, mono-oriented systems, interests, priorities, etc. These priorities are formed within the real state of the national economy, its role and position in the world, ethno - cultural foundations, etc.

According to the sociologist Amitai Etzioni, the assessment of the sovereignty of the nation or self-identification as something sacred, requiring mandatory protection and preservation, appeared in a special historical situation. National sovereignty as a category came into use only in 1648. Until that time, there was no such a thing. The foundations of the world perception, which is inherent by humankind in our time regarding interstate relations, were laid by the conclusion of the Treaty of Westphalia [8, p. 35].

In the context of politics, a sovereign state (with the right to a monopoly of legitimate violence within its territories) has become the subject of interstate relations and the representation of top management in relation to all its citizens.

Articulated and interpreted national and state interests directly related to sovereignty, integrity of territories, carried out in compliance with armed neutrality, etc., are a key factor in the state's foreign policy. The formation of a set of national interests takes place over a long time and gradually, accompanied by a difficult historical interweaving of various circumstances in the sphere of national economy, political strategy, culture, social life, spirituality, morality, etc. its historical past. Consequently, national interests are closely interrelated with the identity of a particular nation.

All the difficulties associated with the nation and its formation directly relate to the interests of the nation, which forces us to consider them in in greater depth.

At the same time, it should be noted that now the number of nations and the number of countries is not the same. On planet Earth, there are many nations that do not have their own countries. One of the many authoritative sociologists and thinkers, the Englishman E. Gellner suggested that nations are divided into real and potential. Only really existing ones have their 
own statehood, while potential ones have no opportunity of acquiring their own state due to the simplicity of their culture and its insufficient level. At the same time, the philosopher says, first of all, about the European continent and those nations that had to become an integral part of the population of the present sovereign states. We are talking about the Scots, Welsh, Flemish, Basques, Walloons, Catalans, Corsicans, etc. The thinker ranked these nations as a category of potential nations, without recognizing their cultural identity [3, p.111]. He, basically, denies them the difference between themselves, comparing their dissimilarity with the dissimilarity of different territorial units within the borders of the country, for example, Italy and Germany, the southern and northern regions of the Russian Federation. In other words, he considers them the ethnological part of the defining nations in their countries (Italians, Germans, French, etc.), believing that they inevitably follow to the fact that they gradually dissolve in these nations and as separate nationalities will completely disappear.

$\mathrm{K}$. Verderi believes that in the quintessence of the concept "nation" laid the ideological and political implications, reflecting the relationship of power with its own citizens. For this reason, it is necessary to explore this concept as a result of its association with different groups. In this context, the study of a nation means the ability to ask about the ways of constructing identities in the social plane and about creating individuals who have them [2, $p$. 300]. With the course of globalization processes and the loss of its former significance by the national state, the nation will not disappear. It simply reorients to other referential communities.

Returning to the research of the topic of interest to us by Russian scientists, I would like to recall that the large-scale economic crisis and the crisis of all public institutions in our country, the collapse of the system of established values and norms, the most powerful collective actions of social groups, political destabilization and interethnic conflicts of the postSoviet period affected the development of sociological sciences. Ethnic sociology received a new impetus in its development. Such directions as relativism, constructivism and instrumentalism adopted new forms specific to Russian realities. In this context, it is worth paying attention to the works of V.A. Tishkov sticking to postmodern ideas. It is also necessary to note the relativistic theory of the nation, advanced by Professor A.G. Zdravomyslovym.

Russian professor V.A. Tishkov in scientific works devoted to the nation used the instrumentalist approach. Starting a study from the analysis of the very basics, he admits in the manner of E. Gellner that only one source and factor in the formation of a nation is the nation-building strategy of the nation state. In other words, "within the nation, in the smallest extent, there is a movement on national self-determination and, to the least extent, nations themselves form national states. On the contrary, the concept of a nation arises within nations in the form of a political program for the formation of independent communities of citizens, and already created states form nations, implementing the process of nation-building" $[10$, p. 88]. Moreover, any of the individuals uses this spiritual impulse to attract the team in the implementation of any social goals that create the best conditions for existence, access to the resource base, management and for their own success in an atmosphere of inequality, dominance and competitiveness [11, p. 78].

According to the author, today in our country, despite the existence of a national state, there is still no nation itself. The main idea of the professor is that Kabardians, Buryats, Lezghins, etc., will inevitably remain pre-national formations until a single Russian nation is created on the basis of a union of all the nationalities of the state. Separate nation-building of these ethnic groups is impracticable, since in our country there are no, and there can be no prerequisites for the emergence of such subjects as nation states of nations that are able to implement such processes. V.A. Tishkov believes that a nation is a figment of the imagination of scientists (followers of scholasticism); it is a combination of sentiments and sensations, an intricate set of criteria, feelings and personality-collectivist strategies [6, p. 87]. 
In fact, the historical process of formation and evolution of a nation and the identification of its interests is a historical process of confrontation for the formation of national statehood, in accordance with the nation of the form and conditions of political and legal existence, the norm of global improvement.

Despite the large number of diverse social communities and groups, united for come grounds or reasons, only national solidarity (except for such a community as a family) is capable of having the most impressive emotional impact, has the greatest spiritual and moral solidarity. National solidarity is characterized by a considerable alogical capacity for unity, the awakening of spiritual impulses in the form of universal love and hatred, especially in the face of danger from abroad. Nationwide solidarity is a moral phenomenon that cannot be accurately measured or traced. The roots of this phenomenon lie directly in the fundamental principles of national existence. стабильность, определительность, интенсивность, солидарность [1, с. 36]. However, despite full being of the national life in the collective essence in all respects, through which it is in structural connection with the outside world, its dissolution in this substance does not occur. So, M.O. Mnatsakanyan believes that the structure of this collective entity includes: a) the social form of the union of individuals; b) methods of grouping and coordinating them; c) subjects of conditional interaction; d) external environment and aspects contributing to their cohesion (territorial, linguistic characteristics, etc.); e) the basic internal characteristics of this social form of union and interaction - historicism, stability, determination, intensity, solidarity [1, p. 36].

According to some theorists, the nation and the state are the same things. For example, V.B. Pastuhov wrote an article in the journal Polis in 2000, stating in it an opinion about the identity of these concepts. The author began his narration with completely objective arguments about the natural relationship between a nation and a nation-state. Then he began to deify this relationship so much that he even uttered the following: "the state and the nation are one subject and have such relation to each other as content and form. These categories represent one public entity in the form of a nation-state or a state-nation." From this statement, it follows that the existence of a nation is possible with the existence of a state. And, on the contrary, the existence of a nation ceases with the disappearance of the state.

We believe that the nation is both the starting point for the formation of the state and the embodiment for a more complete, comprehensive life force, a creative source, and socially important aspects for society and an individual. In case of loss of power, the nation multiplies its strength, gathering them into a fist with the aim of self-preservation and further evolution. At this moment, the question of achieving national and interstate security, as well as security of the state in the sphere of energy and food, comes to the fore.

Thus, the state as a social subject serves the nation, fulfilling certain functions in relation to it, including its protection and defense of its interests, stimulating its evolution and advancement by organizing extremely favorable conditions inside and outside the country, organizing the work of individuals and communities to implement these goals. The functions of the national state include the development and implementation of a security strategy, an allencompassing improvement and growth of the nation, the development of culture, spirituality, enlightenment of the nation, and the enhancement of its socio-economic well-being. The national state also performs the function of the future institutionalization of national life, the formation of civil society, the protection of individual rights, etc.

The issues of national consciousness and self-consciousness began to be studied specially only in the 50 s of the last century. Previously, they were studied along the way to the study of the problems associated with national ideology. As the difference between categories of "national consciousness" and "nationalism" was realized, the concepts of "selfawareness" and "self-identity" have become of particular importance. American scientists, supporters of the socio-psychological direction, J. Davis and A. Maslow became pioneers in the development of this problematic. The first Russian scientists who made a lot of discover- 
ies in this field were V.I. Kozlov, L.M. Drobizheva, Yu.V. Bromley and other researchers at the Institute of Ethnology and Anthropology. Z.V. Sikevich, R.G. Abdulatipov also published research papers on issues of national identity. L.M. Drobizheva described the historical process of creating the Russian doctrine of national identity.

Before you begin to study the history of the formation of national identity, as well as approach the development of political mechanisms for the preparation of national interests, you must first understand the structure of national identity, to determine its main components.

The multi-level, mobility of national identity is determined by national psychology in the form of a non-static and psycho-ideological moral unity. At the initial level, the comprehension of national-cultural and national-psychological data proceeds, as a rule, unconsciously, intuitively, in the form of imitation, but then, at the next level, it is already comprehended, in the process of socialization. Just this last, speculative-conceptual level of national selfconsciousness and passing identification form the ideological and spiritual basis of the struggle against nationalism, which self-consciousness is not able to achieve at the everyday, generally accepted, widespread among the masses.

In addition to psychology, national consciousness is also associated with ideology. However, ideology is associated with a "built" reality and is aimed at practical personal interests. Structured national realities are certain ideologems that are spread in the minds of the masses in order to implement and defend specific political intentions and tendencies and interests of communities that stand out as national. Those ideologems that form the basis of a national ideology should, in the right way, explain facts and problems, provide a plan and a vector of movement towards the realization of certain goals and interests.

However, the outlines, the explicit form of the interest of the nation, to some extent, is consistent with an ideal that reflects the values of this society. An ideal is impossible, if not self-preservation, the maintenance of which lies on the shoulders of only a sovereign nationstate.

At the same time, the leaders of the states should not elude the probable responses to these decisions on the part of those countries whose interests they in any way affect.

There is a whole range of standard norms, the non-observance of which speaks of the unviable state in asserting its own sovereignty. In the course of developing the total number of national interests and making the necessary decisions of internal and external strategic nature on their basis, the leaders of the countries analyze aspects of their geographic, economic, political, cultural and other characteristics, interests of the internal policy orientation, political programs of various parties, movements, communities and so on. At the same time, the likely responses to these decisions on the part of those countries whose interests they are in particular should not elude the attention of state leaders.

Due to the contradictions of interests of different states, large conflicts arise, but in international relations, they are mostly caused by inaccurate and / or incompletely defined and incorrectly perceived interests of the nation or taken national security measures. In any case, the key stimulus of foreign policy initiative is national or state interest, but at the same time, the doctrine of interest of a nation is always based on value norms and ideological content.

In today's environment of global change and mutual penetration of political subjects, the quintessence, the identification and implementation of the interests of the nation needs to be clarified in numerous nuances. In today's conditions of the internationalization of most of the international processes and the growth of the role of international organizations, the concept of "national interest" itself is not entirely clear and what it implies is uncertain. It remains unclear the spectrum and content of the interests of the nation with the intensification of the interests of regions and narrow groups, taking into account the fact that the process of deidentification and, most likely, the destruction of national-state sovereignty has been launched. These alarming uncertainties have a real background. Many researchers have raised the question of the acute urgency of the very problems of understanding the national 
interest in the current conditions of globalization. Nevertheless, as long as national states are available, national interests will not cease to represent a certain interest as a subject of study for scientists, politicians, and analysts.

\section{Лumepamypa}

1. Арутюнян Ю. В., Дробижева Л. М., Сусоколов А. А. Этносоциология. М.: Аспект-Пресс, 1999, 271 с.

2. Вердери К. Нации и национализм, М., 2012.

3. Геллнер Э. Нации и национализм, М., 1991.

4. Кортунов С.В. «Имперское» и национальное в российском сознании // Международная жизнь, 2018. № 6.

5. Молчанов М.A. Дискуссионные аспекты проблемы «национальный интерес» // Полис, 2010. № 1.

6. Мнацаканян М.О. Нации и национализм. М., 2004.

7. Новосельцев $B$. Национальные интересы России (социально-экономический аспект). М., 2007.

8. Пастухов В.Б. Национальные и государственные интересы России: игра слов или игра в слова? // Полис. 2000. № 1.

9. Саидов З.А., Бидова Б.Б. Методологические основания определения национальной безопасности как теоретико-правовой категории // Финансовая экономика, 2018. № 6.

10. Тишков В.A. Дилемма новой России как многоэтничного государства // Права человека и международные отношения. Материалы международного симпозиума 18-20 апреля 1994 г. М., 1994. Ч. І.

11. Тишков В.А. Очерки теории и этничности в России. М., 1997.

12. Фурман Д. Внешнеполитические ориентиры России // Россия и мусульманский мир. Бюллетень реферативно-аналитической информации. 2015. № 12 (42).

13. Этциони A. От империи к сообществу: новый подход к международным отношениям. М., 2014.

14. Rosenau J. The National Interest: Normative Foundation // Review of Politics. 1986. Autumn. Vol. 43.

\section{References}

1. Arutyunyan Y. V., Drobizheva L. M., Susokolov A. A. Etnosotsiologiya [Ethnosociology]. Moscow: Aspekt-Press, 1999. 271 p. (in Russian).

2. Verderi K. Natsii i natsionalizm [Nations and Nationalism]. Moscow, 2012 (in Russian).

3. Gellner E. Natsii i natsionalizm [Nations and Nationalism]. Moscow, 1991 (in Russian).

4. Kortunov S.V. «Imperskoe» i natsionalnoe v rossiyskom soznanii. Mezhdunarodnaya zhizn [Imperial and National in the Russian Consciousness. International Affairs]. 2018. No. 6 (in Russian).

5. Molchanov M.A. Diskussionnyie aspektyi problemyi «natsionalnyiy interes» [Discussion aspects of the "national interest" problem]. Polis. 2010. No. 1 (in Russian).

6. Mnatsakanyan M.O. Natsii i natsionalizm [Nations and Nationalism]. Moscow, 2004 (in Russian).

7. Novoseltsev V. Natsionalnyie interesyi Rossii (sotsialno-ekonomicheskiy aspekt) [National interests of Russia (socio-economic aspect)]. Moscow, 2007 (in Russian). 
8. Pastuhov V.B. Natsionalnyie i gosudarstvennyie interesyi Rossii: igra slov ili igra $v$ slova? [Russia's national and state interests: a pun or a word game?]. Polis. 2000. No. 1 (in Russian).

9. Saidov Z.A., Bidova B.B. Metodologicheskie osnovaniya opredeleniya natsionalnoy bezopasnosti kak teoretiko-pravovoy kategorii. Finansovaya ekonomika [Methodological basis for the definition of national security as a theoretical and legal category. Financial economy]. 2018. No. 6 (in Russian).

10. Tishkov V.A. Dilemma novoy Rossii kak mnogoetnichnogo gosudarstva. Prava cheloveka i mezhdunarodnyie otnosheniya. Materialyi mezhdunarodnogo simpoziuma 18-20 aprelya 1994 [The dilemma of new Russia as a multi-ethnic state. Human rights and international relations. Proceedings of the International Symposium April 18-20, 1994]. Moscow, 1994. P. I (in Russian).

11. Tishkov V.A. Ocherki teorii i etnichnosti v Rossii [Essays on Theory and Ethnicity in Russia]. Moscow, 1997 (in Russian)

12. Furman D. Vneshnepoliticheskie orientiryi Rossii. Rossiya i musulmanskiy mir. Byulleten referativno-analiticheskoy informatsii [Foreign policy guidelines of Russia. Russia and the Muslim world. Bulletin of abstract analytical information]. 2015. No.12 (42) (in Russian).

13. Ettsioni A. Ot imperii k soobschestvu: novyiy podhod k mezhdunarodnyim otnosheniyam [From empire to community: a new approach to international relations]. Moscow, 2014 (in Russian).

14. Rosenau J. The National Interest: Normative Foundation. Review of Politics. 1986. Autumn. V. 43. 